\title{
Concept and Relevance of Vocational Interests in Career Development: A Theoretical Study
}

\author{
Karen Cristina Alves Lamas ${ }^{1}$ \\ Universidade Salgado de Oliveira, Juiz de Fora, MG, Brazil
}

\begin{abstract}
Vocational interests have been researched since the early twentieth century. During that time several theories about career development addressed the importance of their evaluation. The aim of this paper is to present conceptual definitions and developmental processes of interests according to four theories widely publicized, including in the Brazilian context. Thus, from the review of the Theory of Vocational Personalities, the Developmental Theory, the Socio-Cognitive Theory of Career Development and Constructivist Theory of Savickas was found that there is no conceptual oppositions between the definitions. But the current literature supports the concept of trait or disposition relatively stable to respond to environmental stimuli. Regarding the assumptions underlying the formulation of interests there are emphasis differences in some variables, for example, learning experiences and sociocultural conditions. It emphasizes the need for further research, especially in the national context, that has a longitudinal design, seeks to contextualize the variables involved in the development process, and build assessment tools that can be used in educational and organizational contexts.
\end{abstract}

Keywords: Professional development, professional interests, career choice, literature review.

\section{Conceito e Relevância dos Interesses Profissionais no Desenvolvimento de Carreira: Estudo Teórico}

\section{Resumo}

Os interesses profissionais vêm sendo pesquisados desde o início do século XX. Ao longo desse tempo várias teorias sobre o desenvolvimento de carreira abordaram a importância de sua avaliação. O objetivo do presente artigo é apresentar definições conceituais e processos desenvolvimentais dos interesses de acordo com quatro teorias amplamente divulgadas, inclusive no contexto brasileiro. Assim, a partir da revisão da Teoria das Personalidades Vocacionais, da Teoria Desenvolvimentista, da Teoria Sociocognitiva do Desenvolvimento de Carreira e da Teoria Construtivista de Savickas foi verificado que não há grandes divergências entre as definições conceituais. Porém, a literatura atual apoia o conceito de traço ou disposição relativamente estável para responder a estímulos do ambiente. Quanto às hipóteses que fundamentam a formulação dos interesses há diferenças de ênfase em algumas variáveis, por exemplo, experiências de aprendizagem e condições socioculturais. Ressalta-se a necessidade de novas pesquisas, principalmente no contexto nacional, que possuam delineamento longitudinal, busquem

Mailing address: Universidade Salgado de Oliveira - UNIVERSO, Av. dos Andradas, 731, Morro da Glória, Juiz de Fora, MG, Brazil 36036-000. E-mail: karen_lammas@yahoo.com.br

This paper is based on the author's doctorate thesis, developed with the support of Fundação de Amparo à Pesquisa do Estado de São Paulo - FAPESP and of the Coordenação de Aperfeiçoamento de Pessoal de Nível Superior-CAPES. 
contextualizar as variáveis envolvidas no processo de desenvolvimento, e construir instrumentos de avaliação que possam ser utilizados em contextos educacionais e organizacionais.

Palavras-chave: Desenvolvimento profissional, interesses profissionais, escolha profissional, revisão de literatura.

\section{Concepto y Relevancia de los Intereses Profesionales en el Desarrollo Profesional: Estudio Teórico}

\section{Resumen}

Los intereses profesionales se han estudiado desde principios del siglo XX. Durante ese tiempo varias teorías sobre el desarrollo profesional abordaron la importancia de la evaluación. El propósito de este trabajo es presentar los conceptos y los procesos de desarrollo de los intereses de acuerdo a cuatro teorías ampliamente publicitados, incluso en el contexto brasileño. Así, a partir de la revisión de la Teoría de Personalidades Profesional, la Teoría del Desarrollo, la Teoría Socio-Cognitiva de Desarrollo Profesional y Teoría Constructivista del Savickas no hubo grandes diferencias entre las definiciones conceptuales. Sin embargo, la literatura actual apoya el concepto de rasgo o disposición relativamente estable para responder a los estímulos ambientales. Con respecto a los supuestos que subyacen en la formación de los intereses, diferencias de énfasis sobre algunas variables se verificaron, por ejemplo, las experiencias de aprendizaje y las condiciones sociales y culturales. Se hace hincapié en la necesidad de una mayor investigación, especialmente a nivel nacional, que buscan un diseño longitudinal, contextualizar las variables que intervienen en el proceso de desarrollo, y construir instrumentos de evaluación que se pueden utilizar en contextos educativos y organizativos.

Palabras clave: Desarrollo profesional, intereses profesionales, escogimiento profesional, revisión de literatura.

In the year 2013, the National Career Development Association completed one hundred years of existence, and, to celebrate, a monograph with the key concepts and practices that boosted the career development field during this centenary was built. Among these concepts, such as career adaptability, vocational guidance, social justice and professional self-efficacy, the inventory of interest is inserted. To Savickas (2013), the inventory of interests is among the ten vital ideas of the area because the assessment of the professional interests contributes in intervention processes aimed at human development in transitional periods throughout life. Moreover, it is a recurring theme in literature (Leitão \& Miguel, 2001; Sodano, 2015). Thus, it is considered important to provide a review of the concept of Interests to those concerned with research and/or evaluation of this psychological construct.

The early studies on professional interests date back to the first half of the twentieth century (e.g., Fryer, 1931) and were mainly carried out in order to build inventories, such as the Strong Vocational Interest Blank (SVIB) in 1928, and the Kuder Preference Record-Vocational, in 1938 (Harrington \& Long, 2013; Mattiazzi, 1977). Although several authors have sought, over the years, to conceptualize professional interests and explain their development process, the work was carried disjointedly and focused on empirical data, in a way that they did not reflect the evolution of the concept (Leitão \& Miguel, 2001; Savickas, 1999).

In order to understand the conceptualization of interests aligned with this empiricist approach, theoretical contributions on the construct that allow its evaluation through inventories or self-report instruments will be presented (Werlang, Villemor-Amaral, \& Nascimento, 2010). Such theories are widely used in intervention processes and investigated in the Brazilian and international context. Specifically, four theoreti- 
cal approaches are analyzed, namely the theory of vocational personalities (Holland, 1997), the socio-cognitive theory of career development (Lent, Brown, \& Hackett, 1994), Super's developmentalist theory (1980) and constructivist theory of Savickas (1995).

The theory of vocational personalities of Holland (1997) and the socio-cognitive theory (Lent et al., 1994) offer specific hypotheses on the professional interests that are thoroughly investigated by empirical studies. Differently, the developmental theory of Super (1980) and the constructivist theory of Savickas (1995), although they have made important conceptual contributions on professional interests, this construct is secondary to others (e.g., career boss, vocational maturity, adaptability) that make up their theoretical models. Therefore, in referring to Interests, their contributions are particularly conceptualization and practical application within vocational guidance models, which justifies the small number of empirical studies that investigated the professional interests based on these perspectives. The statements about the proposed professional interests in each theory and some empirical studies that illustrate the application are cited and stated below.

\section{The Theory of Vocational Personalities and Work Environments}

John Holland (1959, 1996, 1997) developed one of the most traditional theories on the choice of professions that regards the individual's interests, and had its first publications released in the late 1950's. It is worth mentioning that the text published in 1997 will be used mainly, in addition to other author's references.

Holland built his theory based on the experience he had as a vocational counselor, on the literature on the individual and on the development of a first measuring instrument called Vocational Preference Inventory, published in 1958. The author defines the professional interests as a form of expression of the characteristics of personality in the world of work. From his practice, Holland produced a typological model to explain the professional choice, which matches six types of personalities to six models of professional environments, classified under the same terminology. Therefore, the model is known by the acronym RIASEC, which refers to the types described: Realistic, Investigative, Artistic, Social, Enterprising and Conventional. The types can be arranged in that order on the vertices of a hexagon, so that the closer they are to each other, the more similarities they bear. Therefore, the outlook is also called hexagonal model.

People bearing Realistic type characteristics like handcrafts, practical and technical, which need tools, machinery and electronic equipment and tend to avoid environments that require social interaction. The Investigative profile relates to the preference for academic and research activities, which require a certain level of curiosity and analytical skills, avoiding situations that require persuading others. The Artistic type includes people who are recognized as introspective, intuitive and original, who like to express themselves through artistic activities (e.g., literary and musical) and away from the routine and conventional environments (Holland, 1996, 1997).

Individuals of the Social type like to help and understand others, perceive themselves capable of exercising teaching and counseling and avoid mechanical or technical tasks. The Entrepreneur profile involves tasks where there is a need to convince people to achieve organizational or economic goals. People with this profile have leadership and persuasion abilities, and may not have skills to work in research environments. The people of the Conventional type like to systematize, organize and manipulate data and information, and see themselves with entrepreneurial skills and little artistic ability (Holland, 1996, 1997).

According to Holland (1996, 1997), the congruence between personality and occupational environment is directly related to job satisfaction, the level of performance and professional stability. The models of professional environments can be identified by the demands that the environment makes on the employees and the prevalence of a certain type of personality, so if there is a large number of employ- 
ees of the Realistic type, that environment will probably have realistic features. As for the types of personalities, they are the product of specific interactions between personal and socio-cultural factors, such as dealing with peers, inheritance, parental attitude, economic class, physical and social environment.

In order to explain his conception of development, the author suggests that, in childhood, biological factors and experiences of the sociocultural environment contribute to the formation of preference for certain activities and aversion to others. Subsequently, these preferences are transformed into well-defined interests in accordance with the perception of personal satisfaction and rewards. The pursuit of such interests leads to the development of more specialized skills and to the negligence of potential others. Over time, there occurs a differentiation of interest, followed by the solidification of values. This set of events gives rise to different types of interests or vocational personalities. Each individual has a predisposition to exhibit a specific behavioral repertoire and is composed of a combination of preferences and rejections, skills, self-concepts, values and coping styles.

Since interests constitute the expression of personality in the occupational setting, and as stated by Holland (1996, 1997), inventories of interest can be viewed as personality inventories, it can be found, throughout his writings, equivalence in use of these two concepts. Therefore, these are thought as types of interests or vocational personalities. The types are idealized parameters by which individuals can be measured and compared in order to determine an approximation or likeness, in a way that people do not hold features of only one type; individuals show a pattern or personality profile wherein one or two types of interests / character are more prominent. To evaluate the types, the author built an instrument called the Self-Directed Search - SDS, which was translated and validated in a number of countries, including Brazil (Primi, Muniz, Mansion, \& Nunes, 2010).

Interests can be measured since childhood, and mainly used to predict subsequent career choices (Holland, 1996). So as to contribute to the evaluation and measurement of the predictive power of this, Holland (1997) developed secondary concepts, namely Clarity or Differentiation, Consistency, Coherence and Identity.

The sharpness or Differentiation refers to the Clarity of the interest profile, that is, of the dimensions or assessed types assessed, the distance between the highest and the lowest score, the higher this value, that is, the sharpness, the more predictive power of interests it has. Consistency refers to the level of similarity indicated by the hexagonal model, among the most prominent types resulting from the evaluation. The closer the types, the more stable the vocational behavior of the individual is. The congruence, however, is an equivalence between the type and the environment. For example, it is expected from a social person to work in an environment that is also social because they will find the opportunities and rewards they need. Therefore, this index indicates the persistence of the individual in an occupation. Finally, the concept of Identity suggests how clear, stable and in accordance with the objectives and subject skills the profile of interest is.

According to Nauta (2010), the theory of Holland has the usefulness of being easily tested and applied. According to the literature review conducted by the author, the empirical research confirms the existence of the six types RIASEC for people and environments, and the model has been reapplied in many countries and adopted as the basis for many assessment instruments of professional interests.

As for the secondary concepts, the author found that there is support for some hypotheses and the need of more research for others. For the propositions related to the congruence there is empirical support for their association with job security, career satisfaction and persistence, but the effect size tends to be small. For consistency and differentiation, the explanatory capacity has been lower than expected in relation to these variables, whereas to identity, the results of different studies have been contradictory. However, Nauta (2010) claims that there is little research conducted for the investigation of these last three concepts. 
In order to prove the usefulness of the hypothesis of consistency and differentiation, Tracey, Wille, Durr and De Fruyt (2014) adopted a new method of operation of these concepts, in which the entire RIASEC profile is used, as well as the differences between the scores for each type, using the adjustment of the cosine and amplitude. Thus, the authors have shown that in addition to direct links, these concepts also have an important moderating effect between congruence and career outcomes such as satisfaction and occupational stability. Other studies have investigated the types and secondary concepts can be viewed at Hirschi $(2010,2011)$ and Huang and Pearce (2013).

It must be emphasized that the typological model of Holland $(1959,1996,1997)$ is indicated for the classification of professional interests by several authors (Lent \& Brown, 2006a; Savickas, 2005; Super \& Bohn, 1970/1980; among others) who have built theories on occupational development but have not presented a specific instrument for evaluation. The indication of RIASEC model by the authors happens, although they make it clear that the concept of development of interests is distinct from the assumptions of Holland's theory of vocational personalities.

\section{The Socio Cognitive Theory of Career Development}

One of the elaborated approaches recently developed, which includes the development of professional interests, is the socio-cognitive Theory of Career Development. Presented by Lent, Brown and Hackett in 1994, this perspective derived from the Social Cognitive Theory of Bandura (1977, 1982), it brings together the most relevant concepts for the understanding of professional and academic development, specifically regarding the interests, choices and performance in occupational and educational activities. Later, the theory was extended to include the satisfaction / well-being in professional and academic contexts (Lent \& Brown, 2006b, 2008) and career self-management (Lent \& Brown, 2013). It states that theoretical and empirical points that expound on the professional interests are highlighted here.
Lent et al. (1994) understand interests as patterns of taste, aversions and indifferences about activities and functions linked to a profession. To explain the development of professional interests, the authors have come up with a model, in which self - efficacy and results expectations lead to the formation of interests, and such beliefs derive from the combination of personal variables (e.g. ethnical racial origin, sex, and hereditary predispositions), contextual (e.g. educational opportunities, models, social and financial support, family influences), and learning experiences.

The self - efficacy beliefs are related to how much a person considers themselves able to perform a specific task well (Bandura, 1977). It is a construct that has specific domains, in other words, the same individual has different levels of self-efficacy according to different activities. Such beliefs are built along the learning experiences and have four main sources: experience of successes, vicarious learning, verbal persuasion and physiological indicators. These terms were translated by Nunes (2007), more information about the definitions are available in Bandura (1977, 1982) and Pajares and Olaz (2008).

Self - efficacy beliefs usually predict the result of expectations that relate to reward prospects when issuing certain behavior (Bandura, 1977). This anticipation of results is also developed by personal and vicarious learning experiences, interaction with those who are close, cultural and religious institutions and by the media in general (Lent et al., 1994).

Once people tend to prefer tasks where there is the perception of competence and confidence - self-efficacy, as well as the activities, which anticipate positive results - outcome expectations (Bandura, 1977; Pajares \& Olaz, 2008), the contribution of these concepts for the development of professional interests is evident (Lent et al., 1994). For example, experience in software development or video games may lead to interest in the computer science course (Lent \& Brown, 2006a).

Consequently, the emerging interests combined with the beliefs of self-efficacy and outcome expectations lead to the formulation and 
review of objective ${ }^{2}$ related to the profession (Lent et al., 1994; Lent, Hackett, \& Brown, 2004). These intentions of choice of intentions can be altered by many factors, such as financial or educational because, near the choosing time, the contextual conditions filtered by personal factors are influences that exercise a key role, becoming a source of support or obstacle to decision-making, acting as moderators between interests - goals and objectives - actions (Lent et al., 1994). Therefore, the objectives are more consistent when they can be implemented in a near future (Lent \& Brown, 2006a).

It is important to remember that the Socio Cognitive Theory of Career Development (Lent et al., 1994; Lent et al., 2004) comes from the Bandura Theory (1977), so that its fundaments are grounded on the assumption of reciprocal determinism, that is personal, environmental, and behavioral factors keep a triadic relationship in the production of human actions. Thus, the individual has the opportunity to be the agent of their own path of development through reflection upon their beliefs, interests and courses of action (Bandura, 1978/2008). Although the hypothesis proposed by Lent et al. (1994) suggest a direction of influence among the variables, the authors admit the possibility of a bi-directional relationship or that a variable weighs more than another under specific circumstances.

Therefore, Lent et al. (1994; Lent et al., 2004) argue that for some individuals, the interests will not always predict the professional choice, so that the beliefs of self - efficacy and outcome expectancies may have more impact when deciding when opportunities for the implementation of interests are perceived as limited. They add that the choice of objectives and the review of beliefs may happen several times throughout life, especially when the performance in the chosen activity does not occur satisfactorily. This understanding stems from the idea that interests are not static, although necessary events

2 In agreement with other papers published nationally (Ambiel \& Noronha, 2014; Nunes, 2009), the word 'goals' was translated as 'objetivos' and not as 'metas'. of wide significance to modify the beliefs underlying their formation. In an ideal development course, in late adolescence or early adulthood, the interests stabilize and, as time goes by, tend to become more consistent (Lent et al., 1994).

When evaluating interests one needs to consider the desired level of specificity, so that the evaluation may submit activities that together, point to a profession to be followed or indicate fields and areas of knowledge. The evaluation can be even more specific, for example, when examining the interest of psychology students for research activities or clinic. The authors point out that the instruments must be suitable to the customer's characteristics (e.g., age and life experiences); besides, the wording of items is current in the social context (Lent \& Brown, 2006a).

Several studies are being conducted to investigate the proposed hypothesis by the sociocognitive Theory of Career Development (Lent et al., 1994; Lent et al., 2004) within the national context (e.g., Nunes \& Noronha, 2009, 2011) and the international context, (e.g., Byars-Winston Road, Howard, Davis, \& Zalapa, 2010; Tracey, 2010). When performing a meta-analysis, Sheu et al. (2010) aimed at synthesizing relevant data to test the hypothesis of formation of interests and of the professional choice proposed by the socio-cognitive Theory of Career Development (Lent et al., 1994), using studies that investigated the variables through based dimensions in the professional types of Holland (1997). From the data available in 40 articles, it was possible to test two versions of social-cognitive model.

The first version included four variables, namely, self-efficacy, outcome expectations, interests and objectives of choice with samples that investigated the Artistic, Social and Conventional types. The second analyzed, in addition to the above variables, the support and the barriers for choosing, completing six variables in samples with the Realistic, Investigative and Enterprising types. The results were mostly consistent with theoretical expectations. The model with six variables was the one that indicated that a better support to represent the relationship between contextual conditions and objectives as partially 
mediated by self-efficacy and outcome expectations, instead of generating only direct link to the objectives. As for the interests, no discrepancies related to theory were found, once the outcome expectations and self-efficacy contributed to the prediction of interests and, together with them, helped to explain the change in the objectives of choice in both versions.

It is found that the socio-cognitive Theory of Career Development (Lent et al., 1994; Lent et al., 2004) proposes hypotheses to the various relationships to professional development. At the same time, because it was recently drawn up, empirical studies contribute to the refinement of its proposals, particularly with regard to the configuration of the variables involved in choosing professional goals (Sheu et al., 2010). Regarding statements about the development process of interests, those urge the variable research in different contexts and populations, and the results of previous studies are consistent.

\section{The Developmental Theory of Donald Super}

In the developmental theory of Donald Super, interests are part of the personal factors involved in professional decision making along with needs and values, attitudes, performance, capabilities and heredity (Super, 1957). According to the author, the interests can be characterized as positive or negative in relation to occupational situations (Super \& Bohn, 1970/1980), and indicate specific activities and objects through which the values are achieved (Super, 1973).

There is a hierarchical nature toward needs, traits, values and interests. Necessity is the broader concept and, at the same time, at a lower level of awareness, it indicates the lack of something such as love and shelter or the desire to feel fulfilled and do something constructive. The traces refer to the course of action to meet the needs in a given situation. Needs and traits help to understand the behavioral style of the individual, but in order to predict educational or occupational behavior it is necessary to translate the needs into operational objectives. Thus, the values are abstract goals (e.g., altruism, pres- tige and financial results) implicit in the behavior in order to meet the needs, and they can be achieved through different types of activities or specific objects (e.g., social work, science, business), which is called interests (Super, 1973).

Four definitions of interest are proposed by Super (1957; Super \& Bohn, 1970/1980), based on the method through which they are evaluated. The oldest way of evaluation, called 'expressed interests' refers to statements that the individual himself makes about their preference for a particular profession. The 'inventoried interests' are those investigated by means of inventories, which, from statistical foundations, summarize the responses of people to a score relating to groups of occupations or types of occupational activities. The manifested interests' are checked from the comparison between what one says is interesting and the activities that one actually practices. Finally, the 'tested interests' refer to the assessment of the knowledge that the individual has on a particular field, since learning depends on the individual's interest.

According to the author, the study on tested interests did not attract the attention of researchers in general. The expressed interests or preferences are not very reliable when assessed in childhood and early adolescence, because people in this age group think of more unusual professions, published by the media, as rodeo rider or pilot. From the second half of adolescence, the expressed interests tend to be more realistic and although they have some relationship to the inventoried interests, they still have little connection with other factors that make up the professional choice such as skills and values. The manifested interests, whether hobbies or extracurricular activities, relate weakly with the chosen profession, as such activities are generally carried out to maintain relationships with friends or are associated with the phase of life they are living. The manifested interests are dimly related to the results of tests interests. The inventoried interests tend to be stable, whereas preferences may sometimes change; therefore, they are moderately related. However, the choice or entry into the profession itself tends to be inventoried according to the interests, of course, provided that 
the person is able to invest in the desired field (Super, 1957).

It is important to reiterate that the concept of interest is part of a broader theory about career development proposed by Super in which the first writings date back to 1953. According to the author, career development is a process that occurs over life, through the implementation of self-concepts (Super, 1953). Self-concept is the representation of oneself in different roles, situations or positions in which a number of functions are performed and certain relations formed. The vocational self-concept refers to the role that the individual desires to exercise at work, and it is built through the experiences and models, as well as personal variables, such as interests. The degree of job satisfaction is proportional to how much you could develop the self (Super, 1953; Super \& Bohn, 1970/1980). In order to explain this movement, Super started building his theory, initially, through empirical studies in the $1950 \mathrm{~s}$, when he used to understand the career development process from a sequence of stages, which could coincide with certain age groups, namely, growth (up to 14 years of age), Exploration (15 to 24 years of age), Establishment (2544 years of age), Maintenance (45-64 years of age) and Disengagement (from 65 years of age; Super \& Bohn, 1970/1980; Super et al., 1954). In 1980, Super presents an update of his theory, which he called the life span perspective, lifespace. Thus, vocational development stages occur along within a maxi-cycle (life span), but can also occur several times throughout life, becoming as mini-cycles whenever there is the need for new career choices or even personal ones, since this approach to career not only refers to professional development, but also played a set of roles throughout life (life-space).

It is noteworthy that most of the texts dealing in depth with professional interests were published prior to the review of the theory, since the reformulation did not focus on the role of these interests in career development. In a longitudinal perspective or life-span, it is known that the interests begin to be defined in adolescence and tend to remain stable after this phase, so the important stages of life here are Growth and, mainly, Exploration (Super, 1954; Super \& Bohn, 1970/1980; Super et al., 1954).

During the Growth stage, the child tends to make unrealistic choices, interests are being awakened, and recognition of their own skills is still dawning. The development of the self happens by identifying with relevant people in the family and school. At this stage, the development tasks are to, progressively, acquire autonomy in relation to their own behavior; to become aware of the importance of educational and professional achievements; and to acquire the first skills and work attitudes (Super \& Bohn, 1970/1980; Super et al., 1954).

During adolescence and early adulthood, the individual passes through the Exploration stage. This moment is characterized by the search for self-knowledge and professional information, including the trial of certain roles (Super \& Bohn, 1970/1980; Super et al., 1954). This step involves three tasks, namely, crystallization, specification and implementation of an occupational preference. The crystallization of professional interests occurs between 14 and 18 years of age. Such task consists of formulating a general preference that is expressed steadily. This task can be made easily, still, when there is success in the stages of Growth stage. However, in order to accomplish it, the teenager should be aware of the necessity of the task, taking into account their own personal characteristics (e.g., skills and abilities) and information coming from the environment, for example from parents and teachers. The more defined their knowledge of their own interests is, the more differentiated their profile will be, and the easier the task of crystallizing a preference will be as well. Having defined a general preference and completed the exploration of occupations, a particular career to be pursued can be specified. This usually happens between 18 and 21 years of age. Later, the young individual either will implement their own choice or will join a job or specialized educational system to experience the selves in the chosen career (Savickas, 2002; Super, 1957).

The interests are related to the field and the level of an occupation. For instance, in the field of mechanical engineering there are occupations 
of different professional levels, as the engineer, the mechanic, the machine operator. Thus, a person with an interest in engineering may not afford to become an engineer and have the right opportunities for such, and then follow a career as a mechanic (Super et al., 1954). In this sense, the interests are responsible for the direction and persistence within an occupational area, but, apparently, they are not decisive as to the amount of effort that will be put into it. Thus, the more the interests are defined and consistent with the activities performed, the greater the satisfaction of the individual at work (Super, 1957, Super \& Bohn, 1970/1980).

Super is one of the developmental approach to career choice precursors and his theory is widely used in vocational guidance and career contexts. It can be noticed that this theory is concerned not only with research and theoretical constructs, but also with the practical application of his approach (Super, 1983). This perspective has been developed over the years, expanding its domains to other constructs, beyond the initial interests, also relevant to the area of vocational guidance and career (Savickas, 2005).

\section{The Constructivist Theory of Mark Savickas}

In order to conclude the exposition of the theories that explain the professional interests and the relevance of their evaluation, the conceptions of Savickas are presented (1995, 1999, 2002, 2005). This author expanded the perspective of Super (1980), by establishing connections with a constructive approach, in which, in order to comprehend career development, it is necessary to know not only the choosing processes and occupational experiences, but the context in which they occur and the meaning attributed by the individual to his experiences in the search for adaption in the environment where he or she lives. Thus, for Savickas (1995), the interests denote an interaction between individual and environment. In an objective way, the evaluation of interests indicates patterns of tastes, rejection and indifference - an idea shared by authors such as Lent et al. (1994) -, and that subjectively consists of a way of expressing personality- which corroborates with the theoretical perspective of Holland (1997).

As personality expressions, the interests take part on a motivational matrix that includes needs and values (Savickas, 1995). These three variables can help to explain the movement of the individual in the world by answering three questions: 'why', 'what' and 'how' the individual moves. The needs (why) indicate what is lacking for the individual to feel more secure and complete, they drive the individual and generate energy for the movement. The values (what) correspond to the objects or rewards that can satisfy the necessities, in other words, they dictate the movement direction. The interests (how) are the bridge that connects the needs and the values, modulating the movement. For example, some people express the necessity to help as well as to control others. That leads them to altruism (value) and, finally, to develop interest in social occupations such as education, counseling and social assistance. Such professions allow individuals to provide their clients with useful advice, thus, satisfying the support and control necessities. It can be noticed in this definition, that there is great similarity to the conceptions of Super (1973) when it refers to the hierarchy between necessity and interests.

The interests may, as well, be translated as solutions that the individual gives to personal problems, for something that they lacked throughout their existence. The problems are originated within the family context and then are transferred to the social environment. The solution may rise from models that excel in a particular culture as a way to achieve selfrealization in that society. From the narrative and the inventories, it is possible to identify the materials and resources that lead to selfrealization and complete the life project. As behavior style, the interests depend on the environment available and the structure of opportunities. Thus, by comparing them to other constructs as needs and values, they have less stability (Savickas, 1995).

Posteriorly, in the search for a definition that contemplates all the dimensions of the concept of interests, Savickas (1999) makes a revi- 
sion of the main theoretical perspectives regarding the construct. It is concluded that, underlying interests, are cognitive, emotional, volitional and behavioral processes. However, the author did not find a theory to unify the concept, because, each approach described the construct thought a specific propriety. Thus, with the intention of specifying what interest is, the author defined it in two ways, interest as a state and as trace.

The interest as a state of consciousness is characterized by a readiness to think and respond to a specific environment stimulus, such as objects, activities, people and experiences. By identifying a stimulus, the individual turns their attention to it anticipates pleasant feelings and makes a propitious evaluation. This evaluation generates desire (volition) to do something regarding the stimulus (for example, to learn more about it) due to the experience of satisfaction or gratification. This result anticipation leads the individual to a course of action towards the object, with the goal of satisfying desires, needs or personal values. In case the individual really identifies him or herself with the activity, they may incorporate it as a new interest in their already existing system of self-concept, as the symbolic representation of the interest is given by the stimulus that evocates attention and action (for example, I like books). In this way, the interests are an adaptive effort to use the environment in favor of needs and values.

As a trace, interests concern a general disposition to answer to a homogeneous group of specific stimuli, based on interests. Thus, the regular singular form "interest", which denotes a state or action passes to the plural (interests), characterizing a concept or trace. A trace is understood as a dispositional tendency of responses that is consistent and stable to a determined group of environmental stimuli. Through behavior analyses and autobiographies, it is possible to comprehend the facility and frequency with which an interest starts, as well as its duration over time. It is possible to define the relative strength through inventories of interest, that is, how strongly a preference for a particular activity stands out when compared to other interests. Having consciousness of this pre-disposition leads to the localization of a code in the world of work to the development of the existing system of self-concept. The selfconsciousness of this representation promotes the stability and continuity of the disposition.

According to Savickas (1999), regarding the factors that contribute to the origin and development of interests, there is heredity, learning experiences, capacity of perception, identification with models, social roles accommodation, personality expression and self-concept implementation. The author gathered and presented studies and theories about these aspects in an expository manner, without specifying preferences or conclusions that went beyond the descriptions.

It can be noticed that Savickas (1995, 1999) worked the task of delimitating what professional interests are, even though there is nowadays a more comprehensive theory that addresses other aspects of occupational development (Savickas, 2005; Savickas \& Porfeli, 2012). His review and conclusion about the meaning of the term allows under-standing and differentiation from other constructs. Simultaneously, his proposal of conceptualization has theoretical and practical consistency that enables the investigation of interests as psychological construct (Leitão \& Miguel, 2001).

\section{Conclusions}

Once the inventories of professional interests are vital to the career development field (Savickas, 2013), this present study is useful to researchers and professionals of the field when compiling concepts of interests that stem from theories that suggest this type of evaluation. Beyond the descriptive limit, we intend, at this point, to present a conclusion regarding the construct, on the issue, and indicate future research that might continue its theoretical development and practical application.

As observed by other scholars (Leitão \& Miguel, 2001), the definition proposed by Savickas (1999) seems to be the most appropriate, once it was able to integrate existing concepts while defining the construct. The idea 
of professional interests as a trace, the tendency of relatively stable response to a group of stimuli, has been widely accepted (Sodano, 2015). Possibly, this is the most appropriate concept because it comes from a development built from the theoretical review of previous proposals, while the others were based, mainly on practical experience in building inventories or individual components.

As for Holland's theories (1997), Lent et al. (1994) and Super $(1954,1957)$, although there is no consensus on the concept of interests, it can be seen that there are no pronounced differences or conflicts. By bringing together the definitions, it is possible to agree with Hansen (2005), who in his revisiting the concepts of interest, and considers the construct because of three components, namely, personality, motivation/direction and self / identification. In general, the theories presented here refer to professional interest as a specification of preferences, which leads to stability, and can lead an individual to seek certain situations and occupational factors.

As for the development of professional interests, differences between the theories related mainly to the emphasis on the experiences and on the socioeconomic and cultural aspects are noticed. In fact, some theories about career focus more on the content, i.e., elements that compose career development; others focus more on processes, in other words, on the development and interaction of the elements; and there are still those that touch on content and processes (Patton \& McMahon, 2014).

For example, the proposals of Holland (1997) regarding the development of interests include, but not deepen, the explanation of the factors that contribute to the formation of vocational personalities. This theory is not intended to provide developmental explanations, but assumptions of how the interests in its current state are manifested in the workplace. Super $(1954,1957,1980)$, in turn, limits the development of interests to relations with significant others, self and the search for information, claiming the socioeconomic context to have explicit participation only at the time of the formulation of professional goals.
Resuming the observations of Leitão and Miguel (2001), the approach of Savickas (1999) was also observed; it does not deepen the existing relationships throughout the development of interests, and the socio-cognitive theory (Lent et al., 1994; Lent et al, 2004) is the one that clarifies associations with personal and contextual factors, particularly regarding the role of experience in the modulation of interests (Hansen, 2005; Leitão \& Michael, 2001; Patton \& McMahon, 2014). Again, it is worth mentioning here the propositions that Hansen (2005), who searched in literature elements on the development of interests, and summarized the information into two components. The first is related to the creation, referring to socialization and learning factors, also including environmental and psychological influences that shape the interests. The second, called nature, relates to genetics and heredity.

Regarding the assessment in professional guidance and career processes, it is clear that the authors studied in this paper are unanimous in highlighting the relevance of interests, and among them, there are some differences in the use of other variables in the orientation process. Holland (1997), for example, by understanding interests as an expression of personality, proposes a means of assessment which includes aspects such as skills and abilities, whereas $\mathrm{Su}$ per (1983) and Savickas (1999) emphasize that skills and values should be analyzed alongside, and Lent et al. $(1994,2004)$ indicates the beliefs of self-efficacy and outcome expectations. In general, theorists believe that the professional interests are directly related to career goals, and the empirical researches carried out confirm this assumption as well as its consistency or stability over time (Hansen, 2005; Rounds \& Su, 2014; Sodano; 2015).

In summary, the theoretical perspectives gathered in this paper, although different, can be complementary. It is clear, also, that the authors cite one another, suggesting their instruments or indicating the contributions of a particular contribution. Therefore, the goal of this article is achieved as it was possible to know the propositions of some theorists who study and discuss the 
development of professional interests and who contributed to their conceptual evolution.

As for research agenda, further investigation is indicated, including longitudinal investigation in the national context that should be intended to (a) evaluate how the development of interests happen, (b) how the variables contribute to this process, and (c) how the evaluation of interests can be enhanced in order to equip not only those professionals who work directly with professional guidance, but also educators and managers.

The last point must be dealt with urgently, since, in the Brazilian context, there are only five approved psychological tests that evaluate interests for professional use of psychologists (Sistema de Avaliação de Testes Psicológicos [SATEPSI], 2016). However, only two inventories (Bandeira \& Levenfus, 2009; Noronha, Sisto, \& Santos, 2007) and self-expression test are available to be purchased (Jacquemin, 2000; Jacquemin, Okino, Noce, Assoni, \& Pasian, 2006). Other assessment resources are three techniques of visual nature (card games; Coelho, 2015; Magalhaes, 2011; Neiva, 2015). Therefore, it is necessary to increase the number and diversity of instruments on interests because it would allow different populations to benefit from this knowledge: those who seek guidance in times of choice, and those who attend academic and professional environments and do not resort to a specialized professional when making career-related decisions.

\section{References}

Ambiel, R. A. M., \& Noronha, A. P. P. (2014). Escala de Autoeficácia para Escolha Profissional: Manual técnico (2 ${ }^{\text {nd }}$ ed.). São Paulo, SP: Casa do Psicólogo.

Bandeira, D. R., \& Levenfus, R. S. (2009). Avaliação dos Interesses Profissionais - AIP. São Paulo, SP: Vetor.

Bandura, A. (1977). Self-efficacy: Toward a unifying Theory of Behavioral Change. Psychological Review, 84(2), 191-215. doi:10.1037/0033$295 X .84 .2 .191$

Bandura, A. (1982). Self-efficacy mechanism in human agency. American Psychologist, 37(2),

\section{2-147. doi:0003-066x/82/3702-0122800.75}

Bandura, A. (2008). A evolução da teoria social cognitiva. In A. Bandura, R. G. Azzi, \& S. Polydoro (Eds.), Teoria Social Cognitiva: Conceitos Básicos (pp. 15-42). Porto Alegre, RS: Artmed. (Original work published 1978)

Byars-Winston, A., Estrada, Y., Howard, C., Davis, D., \& Zalapa, J. (2010). Influence of social cognitive and ethnic variables on academic goals of underrepresented students in science and engineering: A multiple-groups analysis. Journal of Counseling Psychology, 57(2), 205-218. doi: $10.1037 / \mathrm{a} 0018608$

Coelho, M. E. (2015). Conhecendo as profissões com a técnica R.O.. São Paulo, SP: Hogrefe Centro Editor de Testes e Pesquisas em Psicologia.

Fryer, D. H. (1931). The measurement of interests. New York: Holt.

Hansen, J. C. (2005). Assessment of interests. In S. D. Brown \& R. W. Lent (Eds.), Career development and counseling: Putting theory and research to work (pp. 281-304). Hoboken, NJ: John Wiley \& Sons.

Harrington, T, \& Long, J. (2013). The history of interest inventories and career assessments in career counseling. The Career Development Quarterly, 61, 83-92. doi:10.1002/j.21610045.2013.00039.x

Hirschi, A. (2010). Individual predictors of adolescents' vocational interest stabilities. International Journal for Educational and Vocational Guidance, 10(1), 5-19. doi:10.1007/s10775-0099171-2

Hirschi, A. (2011). Relation of vocational identity statuses to interest structure among Swiss adolescents. Journal of Career Development, 38(5), 390-407. doi:10.1177/0894845310378665

Holland, J. L. (1959). A theory of vocational choice. Journal of Counseling Psychology, 6(1), 35-45. doi: $10.1037 / \mathrm{h} 0040767$

Holland, J. L. (1996). Exploring careers with a typology: What we have learned and some new directions. American Psychologist, 51(4), 397406. doi:10.1037/0003-066X.51.4.397

Holland, J. L. (1997). Making vocational choices: A theory of vocational personalities and work environments ( $3^{\text {rd }}$ ed.). Odessa, FL: Psychological Assessment Resources.

Huang, J. L., \& Pearce, M. (2013). The other side of the coin: Vocational interests, interest differentiation 
and annual income at the occupation level of analysis. Journal of Vocational Behavior, 83(3), 315-326. doi:10.1016/j.jvb.2013.06.003

Jacquemin, A. (2000). O BBT-Br: Teste de Fotos de Profissões: Normas, adaptação brasileira, estudos de caso. São Paulo, SP: Centro Editor de Testes e Pesquisas em Psicologia.

Jacquemin, A., Okino, E. T. K., Noce, M. A., Assoni, R. F., \& Pasian, S. R. (2006). $O B B T$ $\mathrm{Br}$ Feminino. Teste de Fotos de Profissões: Adaptação brasileira, normas e estudos de caso. São Paulo, SP: Centro Editor de Testes e Pesquisas em Psicologia.

Leitão, L. M., \& Miguel, J. P. (2001). Os interesses revisitados. Psychologica, 26, 79-104. Retrieved from http://staff.fpce.uc.pt//jpacheco/pdf/ Psychologica26_79_104.pdf

Lent, R. W., \& Brown, S. D. (2006a). On conceptualizing and assessing social cognitive constructs in career research: a measurement guide. Journal of Career Assessment, 14(1), 12-35. doi:10.1177/1069072705281364

Lent, R. W., \& Brown, S. D. (2006b). Integrating person and situation perspectives on work satisfaction: A social-cognitive view. Journal of $\mathrm{VO}$ cational Behavior, 69, 236-247. doi:10.1016/j. jvb.2006.02.006

Lent, R. W., \& Brown, S. D. (2008). Social cognitive career theory and subjective well-being in the context of work. Journal of Career Assessment, 16, 6-21. doi:10.1177/1069072707305769

Lent, R. W., \& Brown, S. D. (2013). Social cognitive model of career self-management: toward a unifying view of Adaptive Career Behavior Across the Life Span. Journal of Counseling Psychology, 60(4), 557-568. doi:10.1037/a0033446

Lent, R. W., Brown, S. D., \& Hackett, G. (1994). Toward a unifying social cognitive theory of career and academic interest, choice and performance. Journal of Vocational Behavior, 45, 79-122. doi:10.1006/jvbe.1994.1027

Lent, R., Hackett, G., \& Brown, S. D. (2004). Una perspectiva social cognitiva de la transición entre la escuela y el trabajo. Evaluar, 4, 1-22. Recuperado em http://revistas.unc.edu.ar/index. $\mathrm{php} /$ revaluar/article/view/596/565

Magalhães, M. O. (2011). Matriz de habilidades e interesses profissionais. São Paulo, SP: Casa do Psicólogo.
Mattiazzi, B. (1977). A natureza dos interesses e a orientação vocacional ( $3^{\text {rd }}$ ed.). Petrópolis, RJ: Vozes.

Nauta, M. M. (2010). The development, evolution, and status of Holland's theory of vocational personalities: Reflections and future directions for counseling psychology. Journal of Counseling Psychology, 57(1), 11-22. doi:10.1037/ a0018213

Neiva, K. M. C. (2015). Critérios para escolhas profissionais $\left(3^{\text {rd }}\right.$ ed.). São Paulo, SP: Vetor.

Noronha, A. P., Sisto, F., \& Santos, A. A. A. (2007). Escala de Aconselhamento Profissional -EAP Manual Técnico (Brasil). São Paulo, SP: Vetor.

Nunes, M. F. O. (2007). Escala de Fontes de Eficácia Percebida: Aplicação com jovens em escolha profissional (Master's thesis, Programa de Pós-Graduação Stricto Sensu em Psicologia, Universidade São Francisco, Itatiba, SP, Brazil).

Nunes, M. F. O. L. (2009). Estudos psicométricos da escala de autoeficácia para atividades ocupacionais (Doctoral dissertation, Programa de Pós-Graduação Stricto Sensu em Psicologia, Universidade São Francisco, Itatiba, SP, Brazil).

Nunes, M. F. O., \& Noronha, A. P. P. (2009). Auto-eficácia para atividades ocupacionais e interesses profissionais em estudantes do ensino médio. Psicologia: Ciência e Profissão, 29(1), 102-115. Retrieved from http://www.scielo.br/pdf/pcp/ v29n1/v29n1a09.pdf

Nunes, M. F. O., \& Noronha, A. P. P. (2011). Associações entre auto-eficácia para atividades ocupacionais e interesses em adolescentes. Psicologia: Reflexão e Crítica, 24(1), 1-9. doi:10.1590/ S0102-79722011000100002

Pajares, F., \& Olaz, F. (2008). Teoria Social Cognitiva e autoeficácia: Uma visão geral. In A. Bandura, R. G. Azzi, \& S. Polydoro (Eds.), Teoria Social Cognitiva: Conceitos Básicos (pp. 97-114). Porto Alegre, RS: Artmed.

Patton, W., \& McMahon, M. (2014). Career Developmentand Systems Theory: Connecting theory and practice $\left(3^{\text {rd }}\right.$ ed.). Rotterdam, The Netherlands: Sense.

Primi, R., Muniz, M., Mansão, C. M., \& Nunes, M. F. O. (2010). SDS - Questionário de busca auto-dirigida - Manual técnico da versão brasileira. São Paulo, SP: Casa do Psicólogo.

Rounds, J., \& Su, R. (2014). The nature and power of interests. Current Directions 
in Psychological Science, 23(2), 98-103. doi:10.1177/0963721414522812

Savickas, M. L. (1995). Examining the personal meaning of inventoried interests during career counseling. Journal of Career Assessment, 3(2), 188-201. doi:10.1177/106907279500300206

Savickas, M. L. (1999). The Psychology of Interests. In M. L Savickas \& A. R. Spokane (Eds.), Vocational interests: Meaning, measurement and counseling use (pp. 19-56). Palo Alto, CA: Davies-Black.

Savickas, M. L. (2002). Career construction: A developmental theory of vocational behavior. In D. Brown (Ed.), Career choice and development ( $4^{\text {th }}$ ed., pp. 149-205). San Francisco, CA: Jossey-Bass.

Savickas, M. L. (2005). The Theory and Practice of Career Construction. In S. D. Brown \& R. W. Lent (Eds.), Career development and counseling: Putting theory and research to work (pp. 42-70). Hoboken, NJ: John Wiley \& Sons.

Savickas, M. L. (2013). Ten Ideas that Changed Career Development. In M. L. Savickas (Ed.), Ten Ideas that Changed Career Development (pp. 1-3). Broken Arrow, OK: National Career Development Association.

Savickas, M. L., \& Porfeli, E. J. (2012). Career Adapt-Abilities Scale: Construction, reliability, and measurement equivalence across 13 countries. Journal of Vocational Behavior, 80(3), 661-673. doi:10.1016/j.jvb.2012.01.011

Sheu, H. B., Lent, R. W., Brown, S. D., Miller, M. J., Hennessy, K. D., \& Duffy, R. D. (2010). Testing the choice model of social cognitive career theory across Holland themes: A meta-analytic path analysis. Journal of Vocational Behavior, 76(1), 252-264. doi:10.1016/j.jvb.2009.10.015

Sistema de Avaliação de Testes Psicológicos. (2016). Lista completa dos testes. Retrieved from http:// satepsi.cfp.org.br/listaTesteFavoravel.cfm

Sodano, S. M. (2015). Meaning, measurement, and assessment of vocational interests for career intervention. In P. J. Hartung, M. L. Savickas, \& W. B. Walsh (Eds.), APA Handbook of Career Intervention: Volume 1. Foundations (pp. 281301). Washington, DC: American Psychological Association

Super, D. E. (1953). A theory of vocational development. American Psychologist, 8(5), 185-190. doi:10.1037/h0056046
Super, D. E. (1954). The measurement of interests. Journal of Counseling Psychology, 1(3), 168172. doi: $10.1037 / \mathrm{h} 0059084$

Super, D. E. (1957). The Psychology of Careers. New York: Harper and Row.

Super, D. E. (1973). The work values inventory. In D. G. Zytowski (Ed.), Contemporary approaches to interest measurement (pp.189-205). Minneapolis, MN: University of Minnesota Press.

Super, D. E. (1980). A life-time, life-space, approach to career development. Journal of Vocational Behavior, 16, 282-298. doi:10.1016/00018791(80)90056-1

Super, D. E. (1983). Assessment in career guidance: Toward truly developmental counseling. Personnel and Guidance Journal, 61(9), 555-562. doi:10.1111/j.2164-4918.1983.tb00099.x

Super, D. E., \& Bohn, M. J., Jr. (1980). Psicologia Ocupacional (E. Nascimento \& F. Santos, Trans.). São Paulo, SP: Atlas. (Original work published 1970)

Super, D. E., Crites, J. O., Hummel, R. C., Moser, H. P., Overstreet, P. L., \& Warnath, C. F. (1954). Vocational development: a framework for research. New York: Columbia University.

Tracey, T. J. G. (2010). Relation of interest and selfefficacy occupational congruenceand career choice certainty. Journal of Vocational Behavior, 76, 441-447. doi:10.1016/j.jvb.2009.10.013

Tracey, T. J.G., Wille, B., Durr, M. R., II, \& De Fruyt, F. (2014). An enhanced examination of Holland's consistency and differentiation hypotheses. Journal of Vocational Behavior, 84, 237-247. doi:10.1016/j.jvb.2014.01.008

Werlang, B. S. G., Villemor-Amaral, A. E., \& Nascimento, R. S. G. F. (2010). Avaliação psicológica, testes e possibilidades de uso. In Conselho Federal de Psicologia (Ed.), Avaliação psicológica: Diretrizes na regulamentação da profissão (pp. 101-128). Brasília, DF: Conselho Federal de Psicologia. 